\title{
Large lake drilling projects supported by U.S. National Science Foundation Earth Systems History Program
}

\author{
Sheri Fritz ${ }^{1}$, Thomas Johnson ${ }^{2}$, Paul Baker $^{3}$, Steve Colman ${ }^{2}$, Walter Dean ${ }^{4}$ and John Peck ${ }^{5}$ \\ 1University of Nebraska, Lincoln, USA; sfritz@unl.edu \\ 2University of Minnesota, Duluth, USA; tcj@d.umn.edu; scolman@d.umn.edu \\ 3Duke University, Durham, USA; pbaker@duke.edu \\ ${ }^{4}$ U.S. Geological Survey, Denver, USA; dean@usgs.gov \\ 5University of Akron, USA; jpeck@uakron.edu
}

The U.S. National Science Foundation's Earth Systems History (ESH) Program, in cooperation with the International Continental Drilling Program (ICDP) and the national science foundations of international collaborators, has funded the drilling of several lacustrine basins that contain key continental archives of climate and tectonic history, including Great Salt Lake and Bear Lake (USA 2000), Lake Titicaca (Bolivia/ Peru 2001), Hvitarvatn/Hestvatn/ Huakadalsvaten (Iceland 2003), Lake Bosumtwi (Ghana 2004), Lake Malawi (Malawi 2005), Qinghai (China 2005), and Lake Péten Itzá (Guatemala 2006). These lake drilling projects mark the onset of what could become a systematic acquisition of continuous high-resolution records of continental climate change extending through multiple glacialinterglacial cycles. The projects are generating multi-proxy records of past temperature and hydrological change that can be placed in the context of the rich climatic history derived from the highly successful ocean and ice drilling programs. The ultimate goal of the lake drilling programs is not to confirm the influence of large-scale boundary conditions on global climate, but rather to begin to delineate spatial and temporal deviations from the global mean on the continents where we live, providing important paleoclimate time series to test and improve our models and understanding of global climate dynamics. Below, we highlight science objectives and results to date from a few of these projects, many of which are still in the early stages of analysis.

\section{Lake Titicaca drilling project}

Paul Baker (Duke University, USA), Sheri Fritz (University of Nebraska, USA), Geoff Seltzer (Syracuse University, USA), Mark Bush (Florida Institute of Technology, USA).

Lake Titicaca $\left(17^{\circ} \mathrm{S}, 69^{\circ} \mathrm{W}\right)$ is a high-

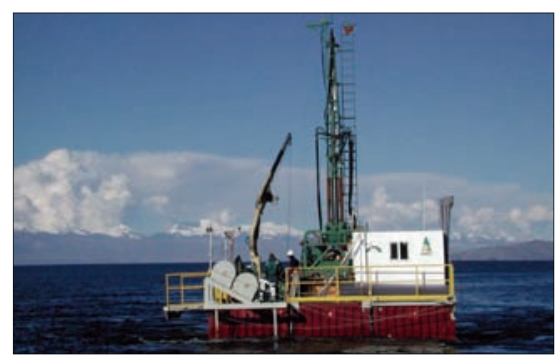

Figure 1: The GLAD800 raft on Lake Titicaca, Bolivia/Peru

elevation (3812 $\mathrm{m}$ ) lake in the tropical Andes of Bolivia and Peru, and was drilled in April/May 2001 using the GLAD 800 drilling platform and coring system (Fig. 1). This site is critical for reconstructing both the timing of regional glaciations and the history of the South American summer monsoon system, and for evaluating how long-term variation in glaciation and effective moisture in the tropical Andes is affected by global-scale glacial boundary conditions, orbitally produced changes in seasonal insolation, and changes in tropical Pacific and/or Atlantic seasurface temperature. The longest recovered sequence spans $136 \mathrm{~m}$ and consists of alternations between two primary lithologic units, indicative of four major regional stages of glacial advance and retreat. Generally, the intervals of increased glaciation were periods when LakeTiticaca was deep and fresh (based on calcium carbonate concentrations, diatom stratigraphy, and $\delta^{13} \mathrm{C}$ isotopic measurements on bulk organic carbon), thus, regional glacial periods were times of high effective moisture and likely high precipitation. A chronology based on radiocarbon, $U$-series ages on aragonite laminae, and tuning to the Vostok $\mathrm{CO}_{2}$ record suggests that the drilled sequence extends over approx. the last 370,000 years. The most recent period of ice expansion in the cordillera surrounding the lake began approx. $60{ }^{14} \mathrm{C}$ ka BP following a major dry interval. The penultimate low stand of LakeTiticaca, rather than dating to the last summer solar minimum ( $32 \mathrm{ka} \mathrm{BP})$, is coincident with MIS5e, the penultimate interglacial stage ( 125 ka BP). This suggests that the water balance of the lake is as strongly influenced by global-scale (and tropical) temperature changes and boundary conditions as by precession forcing of the South American summer monsoon.

\section{Lake Bosumtwi drilling project}

John Peck (University of Akron, USA), Christian Koeberl (University of Vienna, Austria), John King (University of Rhode Island, USA), Bernd Milkereit (University of Toronto, Canada), Jonathan Overpeck (University of Arizona, USA), Christopher Scholz (Syracuse University, USA).

Lake Bosumtwi $\left(6^{\circ} \mathrm{N}, 1^{\circ} \mathrm{W}\right)$ occupies a $1.07 \mathrm{Ma}$ impact crater located in Ghana, West Africa. Bosumtwi is one of only four craters with tektites and contains a thick (300 m) post-impact lacustrine sediment sequence. This hydrologically closed lake is located beneath the path of the seasonal migration of the ITCZ and is ideally situated to provide a long record of North African monsoon variability. In addition, the anoxic bottom water allows for the preservation of finely laminated sediments and the potential for high-resolution (annual) paleoclimate reconstruction. A combined sediment and rock-drilling program was undertaken in summer 2004. Using the GLAD800 lake drilling system, five sites were drilled along a water-depth transect, yielding a total sediment recovery of $1833 \mathrm{~m}$. Drilling in the crater's annular moat recovered $291 \mathrm{~m}$ of sediment. The lowermost lacustrine sediment overlying impact breccia and lapilli is a bioturbated carbonate mud with gastropod shells, indicating that a shallow-water oxic lake was established in the crater. Much of the overlying $291 \mathrm{~m}$ of mud is laminated. Initial study has identified two contrasting lithologies that delineate glacial/ interglacial variability and are read- 
ily correlated to marine sedimentary records. Increased boreal summer insolation and the resulting intensified summer monsoon produce a positive moisture balance. Organicrich sediment with a low-coercivity magnetic mineralogy accumulated during these wet intervals. At times of decreased summer insolation and the accompanying weaker summer monsoon, lake levels fell and a mineral-rich sediment with lower organic content accumulated. During these dry periods, aerosol dust export from the Sahel increased greatly and contributed to a high-coercivity magnetic mineral assemblage. Ongoing sedimentary studies continue to address paleoclimatic questions regarding variability in the North African monsoon and teleconnections between high and low latitudes.

\section{Bear Lake, Utah and Idaho}

Darrell Kaufman (Northern Arizona University, USA), Walter Dean (U.S. Geological Survey, USA), Jordon Bright (Northern Arizona University, USA), and Joseph Rosenbaum (U.S. Geological Survey, USA).

A continuous 120-m-long core collected from Bear Lake, Utah and Idaho $\left(41^{\circ} \mathrm{N} 111^{\circ} \mathrm{W}\right)$ in September 2000 contains evidence of hydrological and environmental change over the last two glacial-interglacial cycles (ca. 250,000 years). Chronological control is provided by ${ }^{14} \mathrm{C}$ dates, paleomagnetic excursion, Useries age, and correlation of carbonate abundance and mineralogy with $\delta^{18} \mathrm{O}$ in Devils Hole calcite. Analyses completed at multi-centennial scale include rock-magnetic properties, $\mathrm{O}$ and $\mathrm{C}$ isotopes on bulk-sediment carbonate and ostracodes, organic- and inorganic-C contents, mineralogy (XRD), Sr isotopes on bulk carbonate, and pollen and diatom assemblages. Most of the core comprises massive to banded silty clay and marl, with variable carbonate content and Oisotopic values. The abundance of siliciclastic sediment indicates that Bear River was usually connected to Bear Lake. Calcite is the dominant carbonate mineral but three aragonitic marl intervals were deposited during the Holocene and the previous two interglacial intervals, equivalent to oxygen isotope stages (OIS) $5 e$ and $7 e$. These intervals have high

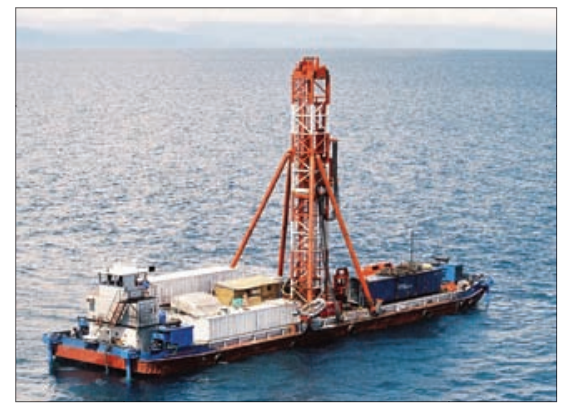

Figure 2: The drilling barge Viphya on Lake Malawi

$\delta^{18} \mathrm{O}$ values (average $=-5.8 \%$ ), indicative of strongly evaporitic conditions when the lake disconnected from the river and retracted into a topographically closed basin. The changing paleoenvironments inferred from these observations are generally consistent with other records of glacial-interglacial fluctuations in the western U.S., with an overprint of catchment-scale processes.

\section{Lake Malawi drilling project}

Christopher Scholz (Syracuse University, USA), Thomas Johnson (University of Minnesota Duluth, USA), Andrew Cohen (University of Arizona, USA), John King (University of Rhode Island, USA), Michael Talbot (University of Bergen, Norway).

Lake Malawi $\left(10-14^{\circ} \mathrm{S}, 35^{\circ} \mathrm{E}\right)$, at the southern end of the East African Rift Valley, provides perhaps the best record of Southern Hemisphere tropical climate dynamics available in Africa. The lake is $580 \mathrm{~km}$ long, $35 \mathrm{~km}$ wide and $700 \mathrm{~m}$ deep, with wind and sea conditions that required a more substantial drilling platform than the GLAD 800, as well as dynamic positioning capability (Fig. 2). Two sites were drilled in February and March 2005: Site 1 in the central basin (water depth $=592 \mathrm{~m}$ ) recovered sediment to $385 \mathrm{~m}$ below lake floor (blf), spanning the past 1.5 million years (preliminary chronology based on dated magnetic reversals and excursions supplemented with radiocarbon, OSL and Be-10 dates), and; Site 2 $(361 \mathrm{~m})$ in the northern basin of the lake was triple cored to a major unconformity at $38 \mathrm{~m}$ blf, recovering a record spanning the past 75,000 years. Two major sediment lithologies dominate the sequences: diatomaceous varved silty mud similar to what is accumulating in anoxic deep basins of the lake today, and bioturbated, ostracode-diatom calcareous silty clay, reflecting more arid condi- tions with oxygenated bottom waters that apparently existed for extended times in the past. One of the surprising results to date was to find that much drier conditions existed prior to 75,000 years ago than during the Last Glacial Maximum.

\section{Lake Qinghai drilling project}

Zhisheng An (Chinese Academy of Sciences, China), Steve Colman (University of Minnesota Duluth, USA), Gerald Haug (GeoForschungsZentrum Potsdam, Germany), Peter Molnar (University of Colorado, USA), and Takayoshi Kawai (Nagoya University, Japan).

Lake Qinghai $\left(36^{\circ} \mathrm{N}, 100^{\circ} \mathrm{E}\right)$, in the People's Republic of China is extremely sensitive to changes in climate because it lies in a critical transitional zone between the humid climate region to the southeast and the dry inland region of the Tibetan Plateau. Three major atmospheric circulation systems affect its climate: (i) the winter monsoon, induced by Siberian high pressure, (ii) tropical moisture from low latitudes, carried by the Asian summer monsoon, and (iii) the westerlies, with their teleconnection to the North Atlantic region. The lake basin occupies a closed tectonic depression, or piggy-back basin, on the upper plate of a major, active thrust fault. Seismic-reflection data show that the lake sediments are tectonically deformed in some parts of the basin and largely undeformed in other parts, where they are more than $700 \mathrm{~m}$ thick. Drilling operations in 2005 were conducted with the GLAD800 coring system, including its enlarged barge. In total, 324 core runs for $548 \mathrm{~m}$ of drilling acquired $323 \mathrm{~m}$ of core at an average recovery rate of $59 \%$. The upper few tens of meters of sediment were mainly gray clay and silty clay, in which core recovery was excellent. The sediments below the clay-rich upper section were mainly fine-grained sand, in which penetration and recovery were poor. The principal investigators thus decided to postpone the planned 700-m drilling for a future campaign and to focus on obtaining high-quality, overlapping cores of the upper $30-50 \mathrm{~m}$ of relatively fine-grained sediment at several sites, in order to obtain a high-resolution record of most of the last glacial cycle. 